\title{
Sığır ve Koyunlarda Eş Zamanlı Brusella ve Şap Aşısı Uygulamalarının Antikor Düzeylerine Etkisi
}

\author{
İbrahim Hanci', İ. Safa Gürcan², Ahmet Sönmez ${ }^{3}$ \\ ${ }^{1}$ Gıda, Tarım ve Hayvancılık Bakanlı̆̆ Şap Enstitüsü, Ankara \\ ${ }^{2}$ Ankara Üniversitesi Veteriner Fakültesi Biyoistatistik ABD, Ankara \\ ${ }^{3}$ TIGGEM Altınova Tarım İsletmesi, Konya
}

Geliş Tarihi / Received: 09.02.2016, Kabul Tarihi / Accepted: 30.05.2016

\begin{abstract}
Özet: Buzağı ve kuzularda brusella ve şap aşılarının eş zamanlı, farklı noktalardan uygulanması ile farklı zamanlarda uygulanması arasında oluşan antikor titrelerinin karşılaştırmalı olarak araştırılması amaçlanmıştır. Parenteral brusella ve şap aşısı 23 adet buzağı ve 105 adet kuzuda çalışılmış ve 12 ay süre ile antikor titreleri izlenmiştir. Konjuktival brusella ve şap aşıs1 91 adet buzağıda çalışılmış ve 2 ay süre ile antikor titreleri takip edilmiştir. Aşılama grupları, her çalışma grubunda hayvanlar üçe bölünerek elde edilmiş ve bu gruplara tek başına şap aşısı, tek başına brusella aşısı ve eş zaman112 aşı uygulaması gerçekleştirilmiştir. Aşılamalardan önce ve aşılama sonrasında 14, 28, 60, 90, 180 ve 360. günlerde kan numunesi alınmıştır. Brusella antikor titresi serum aglütinasyon testi ile şap antikor titresi serum nötralizasyon testi ile saptanmıştır. Sonuç olarak brusella ve şap aşılarının simultane olarak uygulanmasında şap aşısı antikor titrelerinde düşme görülmezken brusella antikor titrelerinde genel olarak artış tespit edilmiştir.
\end{abstract}

Anahtar kelimeler: Antikor, aşı, beraber, brusella, şap hastalı̆̆

\section{The Effect of Simultaneous Application of Brucella and FMD Vaccines on Antibody Level in Cattle and Sheep}

\begin{abstract}
The aim of this research was to investigate the antibody titers of brucellosis, foot and mouth disease (FMD) vaccines and compare differences of application site and application of different times in calves and lambs. Twenty three calves and 105 lambs were vaccinated by brucellosis and FMD vaccines and antibody titer was followed during 12 months. was 91 calves vaccinated by conjunctival brucellosis and FMD vaccines were examined antibody titers for 2 months. In vaccinated groups each group animals were divided 3 parts. First one was for FMD vaccination, second one was for brucellosis vaccination third one was for both vaccination. The blood samples were taken before vaccination and after vaccination in 14, 28, 60, 90, 180, 360 days. The antibody titers to brucellosis vaccine was determined by plate agglutination test. The antibody titers to FMD was determined with Serum Neutralization Test. Finally It was concluded that FMD antibody titers was not affected by simultaneous vaccination of Brucellosis and FMD.
\end{abstract}

Key words: Antibody, brucellosis, FMD, simultaneous, vaccine

\section{Giriş}

Şap hastalığı Picornaviridae familyasına bağlı $A p$ htovirus genusuna ait bir virus tarafindan meydana getirilmektedir $[12,15]$. Virus zarsiz olup tek zincirli RNA taşımaktadır [7,12,15].

Brusella, Birleşmiş Milletler Gıda ve Tarım Teşkilatı (FAO), Dünya Sağlık Örgütü (WHO), Uluslararası Salgın Hastalıklar Ofisi (OIE) tarafından dünyada en yaygın zoonoz olarak kabul edilmektedir.
Brucellosis, campylobacteriosis, salmonellosis ve chlamydiosis koyunlarda en çok tespit edilen atık etkenlerindendir [14,20]. 2003-2007 y1lları arasında Etlik Merkez Veteriner Kontrol ve Araştırma Enstitüsüne gönderilen 463 adet aborte koyun fetusundan en fazla oranda (\% 30,02) Brucella izole ve identifiye edilmiştir [20]. Brusella insanlarda klasik olarak titreme ile yükselen ateş, aşırı terleme, baş ağrısı, halsizlik, bel ve yaygın vücut ağrıları ile seyreden kronik zoonotik infeksiyonlara neden olmaktadir $[3,14]$.

\footnotetext{
*Çalışma aynı zamanda TAGEM/HS/11/01/02/181 nolu TAGEM Projesidir.

**Çalışma için Etik Kurul onayı alınmıştır.
} 
Şap aşısı inaktif, adjuvantlı bir aşı iken brusella aşısı attenüe bir aşıdır. Ülkemizde 2012 Ocak ayı itibari ile sığırlara konjuktival S19, koyunlara konjuktival Rev.1 aşısı uygulanmaktadır.

Aşıların beraber uygulanmasında 3 yol kullanılmaktadır. Aynı anda farklı noktalardan simultane aşılama şeklinde uygulanmaktadır. Ya da kombine aşılama ismi ile nitelendirilen ya 2 aşının uygulamadan hemen önce birleştirilip tek enjeksiyonla verilmesi șeklinde ya da üretim esnasında 2 farklı aşının birleştirilerek tek şişeye konulması şeklinde olmaktadır.

Ülkemizde halen koyun-keçi vebası aşısı ve şap aşısı simultane olarak uygulanmaktadır.

1970 y1lından sonra Fransa'da şap ve inaktif brusella aşıları geniş çapta kombine aşı şeklinde uygulanmıştır. Çalışmalarda beklenen titreler elde edilmiştir [9].

Garcia-Carillo ve ark. (1978), Kathuria ve ark. (1976) simultane aşılamada canlı attenüe aşıların şap aşısına olan immun yanıtı azalttığını ileri sürmüşlerdir. Daha sonra Ortadoğu ve Afrika'da sığır vebasının tekrar görülmesi ile Hedger ve arkadaşlar1 1986 yılında Umman Sultanlığı'nda şap ve sığır vebası için simultane aşılama çalışması yapmıştır. Hedger ve arkadaşları hayvanları 3'e ayrılıp sadece şap, sadece sığır vebası ve şap+sığır vebası simultane şekilde uygulamıştır. Aşılamaların yapıldı̆̆ı gün, 21. gün ve 42. günde kan numuneleri alınıp her iki titre tayini için nötralizasyon testi uygulanmıştır. Gruplar arası fark istatistiki çalışmalar yapılarak ortaya konulmuştur. Hedger ve arkadaşları 1986 yılında simultane aşılamanın titre kaybı olmaksızın güvenle kullanılabileceği sonucunu bulmuşlardır. Afrika ve Ortadoğuda inaktif şap aşısı ve attenüe sığır vebası aşısı simultane olarak ülke hayvanlarına uygulanmıştır.

Mastan ve ark. [16] brusella ve şap hastalığına karşı kombine aşılamanın sonuçlarını görmek için bir çalışma yapmışlardır. Her grubun 5 adet kobaydan oluştuğu 8 grup oluşturmuşlardır. Gruplar; 1Sadece canlı brusella S19 aşısı 2- Sadece şap aşısı 3- Canlı brusella S19 ve şap aş1laması (simultane) 4- Canlı brusella $\mathrm{S} 19$ ve șap aşılaması (kombine) 5Sadece inaktif brusella S19 aşısı 6- İnaktif brucella S19 ve şap aşılaması (simultane) 7- İnaktif brusella S19 ve şap aşılaması (kombine) 8- Kontrol olarak dizayn edilmiştir. Şap aşısı olarak formolle inaktive, alüminyum hidrokside adsorbe, saponinli trivalan aşı kullanılmıştır. Şap virusunun inaktivasyonunda kullanılan formolün canlı brusella aşısı üzerinde zararlı etkisi olup olmadığı ortaya konulmaya çalış1mıştır. Yapılan invivo ve invitro deneylerde formolün kombine aşı içerisindeki brusella S19 üzerinde hiçbir zararlı etkisinin olmadığı tespit edilmiştir. Kobaylara aşılamadan sonra eprüvasyon çalışmas1 uygulanmıştır. Canlı brusella S19 ve şap aşıları gerek simultane gerekse kombine olarak uygulandığında tek yapılan canlı brusella aşılamasına göre daha iyi eprüvasyon sonuçları vermiştir. Canlı brusella S19 ile kombine şap aşılarının inaktif brusella S19 ile kombine şap aşılarına göre titre değerleri ve eprüvasyon değerleri daha yüksek çıkmıştır. Bu durum canlı aşı ile inaktif aşıyı kombine etmenin iki inaktif aşıyı kombine etmeye göre daha iyi titre vereceği görüşüne katk1 sunmuştur. Bu çalıșmada diși ve erkek kobaylar arasında herhangi bir fark tespit edilmemiştir.

İlk simultane aşılama çalışmalarından birini Castaneda ve ark. [6] yapmıştır. Şap aşısı ve canlı vesiculer stomatitis aşısı 4-6 aylık buzağılara simultane şekilde boynun iki yanından yapılmıştır. İlk aşılamadan 3-4 ay sonra aşılamalar tekrarlanmıştır. Sonuç olarak aşılar ayrı ayrı yapıldıklarında oluşan antikor titresi daha yüksek olmamıștır.

Ivanyi ve ark. [11] attenüe viral diare aşısı ile inaktif şap aşısını simultane uygulamışlardır. 18 s1ğır üç gruba ayrılarak bir gruba iki aşı beraber, bir gruba sadece attenüe viral diare aşısı, bir gruba sadece şap aşısı yapılmıştır. On haftalık sürede kan numunesi alınıp nötralizasyon testi yapılmış ve eprüvasyon uygulanmıştır. Hem nötralizasyonda hem eprüvasyon çalışmasında simultane aşılama yapılan grubun diğer gruplardan farkı bulunamamıştır.

Hedger ve ark. [10] 3 gruba ayrilan toplam 118 sığır üzerinde simultane aşılama çalışması yapmıştır. Bir gruba trivalan şap aşısı yapılmış, bir gruba attenüe doku kültürü sığır vebası aşısı yapılmış ve diğer gruba da her iki aşı simultane bir şekilde boynun farklı bölgelerinden yapılmıştır. Serolojik yanıt, virüs nötralizasyon testi ile gözlenmiştir. Simultane şekilde yapılan aşılamada ayrı ayrı yapılanlara göre serolojik cevapta önemli derecede farklılık tespit edilmemiştir. 
Domuz yavrularına De Clercq ve ark. [8] inaktif, adjuvantlı şap ve attenüe klasik domuz ateşi aşılarını simultane uygulamışlardır. Klasik domuz ateşi ile beraber şap aşısı yapılan domuzlarda yalnız şap aşısı yapılanlara göre antikor cevabında bir değişiklik olmaz iken simultane yapılan aşılamada klasik domuz ateşine karşı oluşan antikor titresi tek aşı yapılan gruba göre daha yüksek elde edilmiştir.

Farklı bir çalışmayı ise Srinivas ve ark. [17] şap ve sı̆̆ır vebası aşısı saha koşuları altında simultane şekilde yapılarak aşılı hayvanlarda oluşan antikor üretiminin gelişmesinde interferens etkinin olup olmadığı araştırmıştır. Sonuç olarak aşılar yalnız veya simultane yapıldıklarında herhangi bir yan etki olmaksızın aynı serolojik cevabı oluşturmuştur.

Çalışmanın amacı 2 aşının aynı anda farklı noktalardan uygulanması ile oluşan antikor titresinin izlenerek, simultane aşılamaya zemin oluşturulmasidir.

\section{Materyal ve Metot}

\section{Aşı}

Aş1lamalarda Pendik Veteriner Kontrol Enstitüsü tarafindan üretilen Brucella abortus S19 genç aşı1 (buzağı için, deri altı ve konjuktival), Brucella melitensis Rev.1 genç aşısı (kuzu için, deri altı ve konjuktival) ve Şap Enstitüsü tarafindan üretilen şap aşısı (sığır ve koyunlar için) kullanılmıştır. Şap aşısı olarak Turvac Oil Bivalan, 10/11 seri nolu aşı kullanılmıştır. Brucella abortus S19 aş1s1 olarak 2009/6 seri nolu aşı ve Brucella melitensis Rev.1 aşısı olarak 2010/1 seri nolu aşı kullanılmıştır.

\section{Antijen}

Brusella antikor titrelerini belirlemek için ticari olarak Pendik Veteriner Kontrol Enstitüsü tarafından üretilen Brucella tüp aglütinasyon antijeni; şap virus antikorları için BHK-21 An31 hücresi ve 100 TCID50 virus kullanılmıştır.

\section{Hayvanlar}

Parenteral brusella ve şap aşısı 23 buzağı ve 105 kuzuya uygulanmıştır. Konjuktival brusella ve şap aş1laması 91 adet buzağıya uygulanmıştır. Parenteral çalışmaya alınan buzağılar 90-117 günlük, kuzular 3-6 aylıktır. Konjuktival çalışmaya alınan buzağılar 95-178 günlüktür. Çalışmada Montofon 1rkı buza- $\breve{g} 1$ ve Merinos ırk1 kuzular kullanılmıştır. Gruplar oluşturulurken yaşlara göre dağılım yapılmıştır. Hayvanlar arasında bakım ve beslenme açısından fark bulunmamaktadır. Çalışmalar Konya'nın Kadınhanı İlçesi'nde bulunan TİGEM'e ait Altınova Tarım İşletmesi'nde yapılmıştır.

\section{Serum}

Aş1lamalardan önce ve aşılama sonrasında 14, 28, $60,90,180$ ve 360. günlerde alınan kan serumlarındaki antikor titre düzeyleri belirlenmiştir.

\section{Deneme ve kontrol gruplarının seçimi}

105 kuzu, 23 buzağı ve 91 buzağıdan oluşan 3 grup halinde çalışmalar yapılmıştır. Belirli günlerde alınan kan numunelerinde antikor titre tayini için testler yapılmıştır. Şap antikor titresi için serum nötralizasyon testi, brusella antikor titresi için serum aglütinasyon testi uygulanmıştır.

\section{Deneme grupları}

1 Nolu deneme grubu: buzağ 1 , parenteral brusella ve şap aşısı uygulaması

2 Nolu deneme grubu: buzağı, konjuktival brusella ve şap aş1s1 uygulaması

3 Nolu deneme grubu: kuzu, parenteral brusella ve şap aşısı uygulaması

\section{Kontrol grupları}

1 Nolu kontrol grubu: buzağı, parenteral brusella aş1s1 uygulaması

2 Nolu kontrol grubu: buzağı, konjuktival brusella aş1s1 uygulaması

3 Nolu kontrol grubu: buzağı, tek doz şap aşısı uygulamas1

4 Nolu kontrol grubu: buzağı, 2 doz şap aşısı uygulaması

5 Nolu kontrol grubu: kuzu, parenteral brusella aşıs1 uygulamas1

6 Nolu kontrol grubu: kuzu, tek doz şap aşısı uygulaması

7 Nolu kontrol grubu: kuzu, 2 doz şap aşısı uygulamas1

8 Nolu kontrol grubu: kuzu, 3 doz şap aşısı uygulaması 
Şap aşısı prospektüsüne göre ilk aşılamayı takiben 1 ay sonra ikinci doz aşı uygulanmıştır. İkinci aşılamadan 5 ay sonra 3 . doz aşı uygulanmıştır.

\section{Aşı ve aşılama takvimi}

Tablo1. Aș1lama takvimi

\begin{tabular}{lcccccc}
\hline \multicolumn{6}{c}{ Aşılamalar } \\
\hline & 0. Gün & 28. Gün & 2. Ay & 3. Ay & 6. Ay & 12. Ay \\
\hline Şap+Br. & Ş + B & Ş & & Ş & Ş \\
Şap & Ş & Ş & B & Ş & Ş \\
Br. & B & Ş & Ş & Ş & Ş \\
\hline
\end{tabular}

Brucella abortus S19 genç aşısı, dişi danalara boyundan deri alt1, Brucella melitensis Rev.1 genç aşısı dişi ve erkek kuzulara scapulanın gerisinden deri altı tatbik edilmiştir. Konjuktival aşı konjuktiva ya da konjuktival keseye damlatılmıştır. Bivalan yağ adjuvantlı şap aşısı ise deri altı yolla tatbik edilmiştir. Sıfırıncı gün ve aşılamalardan sonraki antikor titresinin artışını gözlemlemek için 14, 28, 60, 90,180 ve 360. günlerde kan alınmıştır. Bağışıklık brusella aşısında aşılamadan 21 gün sonra, şap aş1sında aşılamadan 28 gün sonra şekillenmektedir.

\section{Serolojik testler}

\section{Serum aglütinasyon testi}

Brusella antikor titre tayini için kullanılmıştır. Doksan altı gözlü U tabanlı plate'in serum dilüsyonu için 6 gözü kullanılmıştır. Reaksiyonların okunmasında göz aldanmalarını önlemek ve hataya düşmemek için her testte bir kontrolle çalışılmıştır (Aslantaş, 2006).

\section{Serum nötralizasyon testi}

Şap antikor titre tayini için kullanılmıştır. 96 gözlü plate'lerde BHK-21 An31 hücresi \%70-80 monolayer hale geldiğinde kullanılmıştır. Virusların 0,1 100 TCID50 olacak şekilde dilusyonları yapılarak test protokolüne uygun şekilde titre tayini yapılmıştır (Şap Enstitüsü Protokolü).

\section{İstatistik sonuçları}

Önemlilik testlerine geçmeden önce veri setleri parametrik test varsayımlarından olan normallik ve varyansların homojenliği yönünden sırasıyla Shapiro Wilk ve Levene testi ile incelenmiştir. Elde edilen sonuçlara göre ayrı ayrı her bir zamanda al1nan ölçümler için gruplar arası farkın anlamlılığ parametrik test varsayımlarını sağlayan değişkenler için Student T testi ile sağlamayanlar için ise Mann Whitney U testi ile incelenmiştir. Sonuçlar minimum $\% 5$ hata payı ile değerlendirilmiştir. SPSS14.1 paket programından yararlanılmıştır.

\section{Bulgular}

\section{Serum nötralizasyon testi sonuçları}

Nötralizasyon testi ile şap antikor titresi belirlenmiştir. $1 / 22$ ve üzeri titreye sahip hayvanlar hastalığa karşı bağışık kabul edilmektedir. Buzağılarda ve kuzularda $1 / 4$ ve $>1 / 44$ arasında değiş̧en maternal antikor titreleri bulunmaktadır. Gruplandırmalar yaş göz önüne alınarak yapıldığından maternal antikorlu hayvanlar gruplara genelde homojen şekilde dağ1lım göstermiştir.

Tablo 2. Parenteral brusella ve şap aşısı uygulanan buzağılarda O tipi şap antikorlarının titre dağılımı

\begin{tabular}{|c|c|c|c|c|c|c|c|c|c|c|c|c|c|c|c|c|c|c|}
\hline & & & $<1 / 8$ & $1 / 8$ & $1 / 11$ & $1 / 16$ & $1 / 22$ & $1 / 32$ & $1 / 44$ & $1 / 64$ & $1 / 96$ & $1 / 128$ & $1 / 192$ & $1 / 256$ & $1 / 362$ & $1 / 512$ & $>1 / 512$ & $\mathrm{n}$ \\
\hline \multirow{10}{*}{ 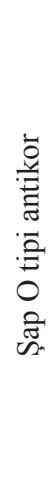 } & \multirow{2}{*}{ 14. Gün } & Ş+B & 1 & & & 2 & 1 & 1 & 2 & 1 & & & & & & & & 8 \\
\hline & & Ş & 1 & & 1 & 4 & 1 & 1 & & & & & & & & & & 8 \\
\hline & \multirow{2}{*}{ 28. Gün } & Ş+B & & & 1 & & 1 & 1 & 3 & 1 & 1 & & & & & & & 8 \\
\hline & & Ş & 1 & 1 & 1 & & 1 & 3 & & 1 & & & & & & & & 8 \\
\hline & \multirow{2}{*}{ 2. Ay } & Ş+B & & & & 1 & 1 & & 1 & 2 & & 2 & & & & & & 7 \\
\hline & & Ş & & & 1 & & & 2 & 1 & 3 & 1 & & & & & & & 8 \\
\hline & \multirow{2}{*}{ 3. Ay } & Ş+B & & & & & 1 & & 2 & 1 & 1 & & & & 1 & 1 & & 7 \\
\hline & & Ş & & & & 1 & & 3 & 2 & 1 & & 1 & & & & & & 8 \\
\hline & \multirow{2}{*}{ 6. Ay } & Ş+B & & 3 & 2 & 1 & 1 & & & & & & & & & & & 7 \\
\hline & & Ş & 2 & 1 & 3 & & & & 1 & & 1 & & & & & & & 8 \\
\hline
\end{tabular}


Açıklama: Nötralizayon testinde $1 / 22$ ve üzeri titreye sahip hayvanların hastalığa karşı korunduğu göz önüne alındığında 14. gün sonuçlarına göre simultane aşılamada buzağıların 5/8'i bağışık iken sadece şap aşılaması yapılan grupta buzağıların $2 / 8$ 'i bağışıktır. 28. günde simultane grup $7 / 8$ oranında bağışık iken sadece şap aşılaması yapılan grup 5/8 oranında bağışıktır. 2. ayda simultane grup 6/7, şap grubu $7 / 8$ oranında bağışık, 3 . ayda simultane grup $7 / 7$, şap grubu $7 / 8$ oranında bağışık, 6 . ayda simul- tane grup $1 / 7$, șap grubu $2 / 8$ oranında bağıșıktır. 6 ayda antikor titrelerindeki düşmeler $\mathrm{O}$ tipi virüs yapisindan kaynaklanmakta olup genel bir durum olarak değerlendirilmektedir. Gruplardaki hayvanlarda korumayı sağlayan en düşük titre baz alınarak yapılan karşılaştırmalarda simultane grubun daha iyi titre verdiği sonucuna ulaşılmaktadır. İstatistiki olarak yapılan karşılaştırmalarda eş zamanlı aşılama yapılan gruptaki buzağıların O tipi antikor titresi ile yalnız şap aşılaması yapılan grup arasında istatistiki olarak fark bulunmamıştır ( $\mathrm{p}>0,05)$.

Tablo 3. Parenteral brusella ve şap aşısı uygulanan buzağılarda A tipi şap antikorlarının titre dağılımı

\begin{tabular}{|c|c|c|c|c|c|c|c|c|c|c|c|c|c|c|c|c|c|c|}
\hline & & & $<1 / 8$ & $1 / 8$ & $1 / 11$ & $1 / 16$ & $1 / 22$ & $1 / 32$ & $1 / 44$ & $1 / 64$ & $1 / 96$ & $1 / 128$ & $1 / 192$ & $1 / 256$ & $1 / 362$ & $1 / 512$ & $>1 / 512$ & $\mathbf{n}$ \\
\hline \multirow{10}{*}{ 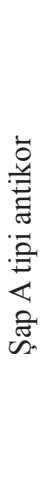 } & \multirow{2}{*}{ 14. Gün } & Ş+B & & & 3 & 2 & 2 & & 1 & & & & & & & & & 8 \\
\hline & & Ş & & & 2 & 2 & 3 & 1 & & & & & & & & & & 8 \\
\hline & \multirow{2}{*}{ 28. Gün } & Ş+B & & 1 & & 1 & 4 & 1 & 1 & & & & & & & & & 8 \\
\hline & & Ş & & 1 & 2 & 1 & 2 & 1 & 1 & & & & & & & & & 8 \\
\hline & \multirow{2}{*}{ 2. Ay } & Ş+B & & & & & & & & & 1 & & 1 & & 1 & 3 & 1 & 7 \\
\hline & & Ş & & & & & & & & & & 1 & & & 3 & 4 & & 8 \\
\hline & \multirow{2}{*}{ 3. Ay } & Ş+B & & & & & & & & & 2 & 2 & 1 & & 1 & 1 & & 7 \\
\hline & & Ş & & & & & 1 & & 2 & & 1 & 3 & & & & & 1 & 8 \\
\hline & \multirow{2}{*}{ 6. Ay } & Ş+B & & & & 1 & 2 & 1 & 1 & & 1 & & 1 & & & & & 7 \\
\hline & & Ş & & & & & & 1 & 3 & & 1 & 1 & 2 & & & & & 8 \\
\hline
\end{tabular}

Açıklama: 14. gün sonuçlarına göre simultane aşılamada buzağıların 3/8'i bağışık iken sadece şap aşılamasında buzağıların 4/8'i bağışıktır. 28. günde simultane grup 6/8 oranında bağışık iken, sadece şap aşılaması yapılan grup 4/8 oranında bağışıktır. 2 . ve 3.ayda simultane grup $7 / 7$, şap grubu $8 / 8$ oranında bağışık, 6 . ayda simultane grup 6/7, şap grubu 8/8 oranında bağışıktır. Gruplardaki hayvanlarda korumayı sağlayan en düşük titre baz alınarak yapılan karşılaştırmalarda grupların birbiri ile uyumlu sonuç gösterdiği düşünülmektedir. İstatistiki olarak yapılan karşılaştırmalarda eş zamanlı aşılama yapılan gruptaki hayvanlar ile yalnız şap aşılaması yapılan grup arasında A tipi antikor titresi açısından istatistiki olarak fark bulunmamıştır $(\mathrm{p}>0,05)$.

Tablo 4. Parenteral brusella ve şap aşısı uygulanan kuzularda $\mathrm{O}$ tipi şap antikorlarının titre dağılımı

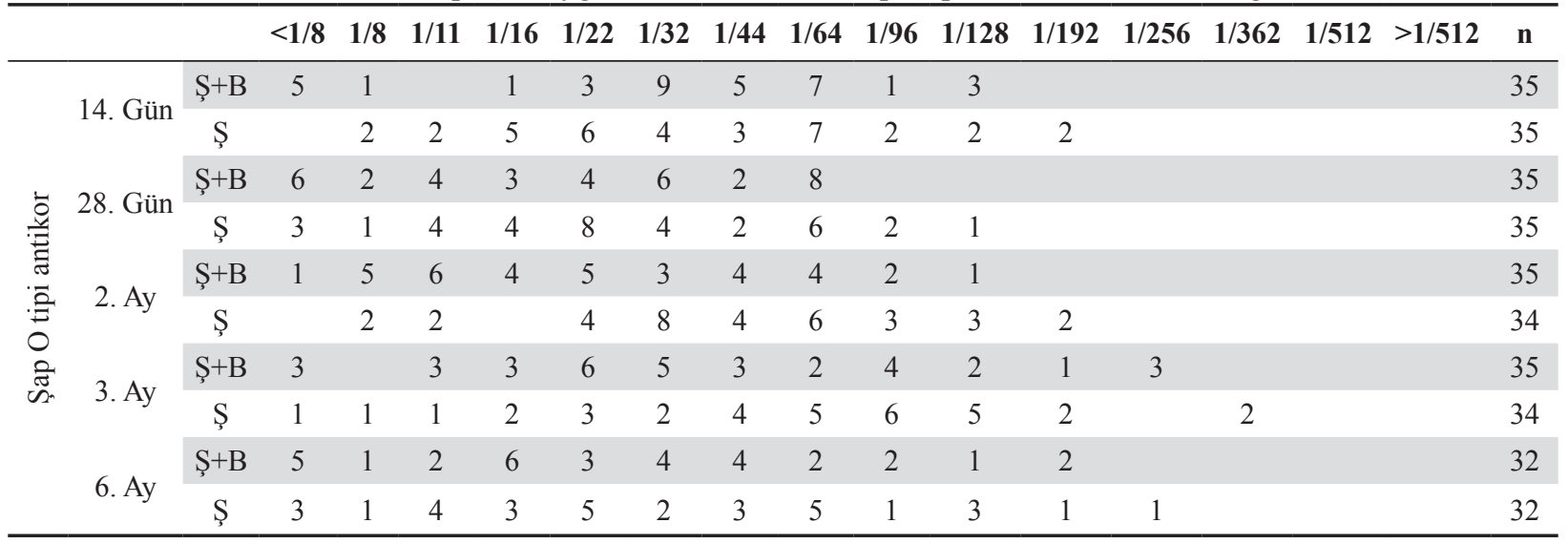


Açıklama: 14. gün sonuçlarına göre simultane aşılamada kuzular 28/35 oranında bağışı iken sadece şap aşılamasında buzağıların 26/35 oranında bağışıktır. 28. günde simultane grup 20/35 oranında bağışık iken, sadece şap aşılaması yapılan grup 23/35 oranında bağışıktır. 2. ayda simultane grup $19 / 35$, şap grubu $30 / 34$ oranında bağışık, 3. ayda simultane grup 26/35, şap grubu 29/34 oranında bağışık, 6. ayda simultane grup 18/32, şap grubu 21/32 oranında bağışıktır. Gruplardaki hayvanlarda korumayı sağlayan en düşük titre baz alınarak yapılan karşılaştırmalarda genel olarak şap grubunun titrelerinin yüksek olduğu görünmektedir. Bunun sebebi olarak simultane grupta maternal antikor gösteren hayvan 1/35 oranında iken şap grubunda 32/35 olmasından kaynaklandığ düşünülmektedir. Çalışmadaki kuzuları yetiştiren işletme kayıtlarında kuzuların doğum tarihi bulunmadığından gruplandırmada yaş esas alınamamıştır. Bu sebeple şap grubuna maternal antikoru yüksek kuzular isteğimiz dışında denk gelmiştir. 2. ayda eş zamanlı grubun O tipi antikor titresi yalnız şap aşılaması yapılan grubun antikor titresinden istatistiki olarak düşük çıkmıştır $(\mathrm{p}<0.05)$. Bu durumunda maternal antikor sebebi ile kaynaklandığı düşünülmektedir.

Tablo 5. Parenteral brusella ve şap aşısı uygulanan kuzularda A tipi şap antikorlarının titre dağılımı

\begin{tabular}{|c|c|c|c|c|c|c|c|c|c|c|c|c|c|c|c|c|c|c|}
\hline & & & $<1 / 8$ & $1 / 8$ & $1 / 11$ & $1 / 16$ & $1 / 22$ & $1 / 32$ & $1 / 44$ & $1 / 64$ & $1 / 96$ & $1 / 128$ & $1 / 192$ & $1 / 256$ & $1 / 362$ & $1 / 512$ & $>1 / 512$ & $\mathbf{n}$ \\
\hline \multirow{10}{*}{ 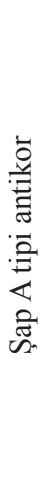 } & \multirow{2}{*}{ 14. Gün } & Ş+B & 1 & & 1 & 1 & 3 & 5 & 6 & 6 & 5 & 4 & 2 & 1 & & & & 35 \\
\hline & & Ş & 1 & 1 & 1 & 1 & 3 & 5 & 5 & 2 & 9 & 3 & 2 & 2 & & & & 35 \\
\hline & \multirow{2}{*}{ 28. Gün } & Ş+B & 2 & 3 & & 2 & 5 & 8 & 6 & 4 & 5 & & & & & & & 35 \\
\hline & & Ş & 1 & 4 & 3 & 1 & 3 & 2 & 12 & 2 & 6 & & 1 & & & & & 35 \\
\hline & \multirow{2}{*}{ 2. Ay } & Ş+B & & & & & & 2 & 2 & & 2 & 3 & 4 & 6 & 9 & 4 & 3 & 35 \\
\hline & & Ş & & & & & & 1 & & 2 & & 2 & 5 & 6 & 7 & 9 & 2 & 34 \\
\hline & \multirow{2}{*}{ 3. Ay } & Ş+B & & 1 & & 1 & 5 & 1 & 3 & 5 & 3 & 4 & 3 & 3 & 4 & 1 & 1 & 35 \\
\hline & & Ş & & & & 1 & 1 & 1 & 6 & 6 & 6 & 3 & 1 & 4 & 1 & 4 & & 34 \\
\hline & \multirow{2}{*}{ 6. Ay } & Ş+B & 1 & & 2 & & 3 & 2 & 4 & 7 & 4 & 2 & 2 & 3 & 1 & & 1 & 32 \\
\hline & & Ş & & & & 2 & 1 & 1 & 4 & 3 & 6 & 4 & 7 & 2 & 1 & & 1 & 32 \\
\hline
\end{tabular}

Açıklama: 14. gün sonuçlarına göre simultane aşılamada kuzuların 32/35'i bağışık iken sadece şap aşılaması yapılan grupta kuzuların $31 / 35$ 'i bağış1ktır. Bu şekilde 28. günde simultane grup 28/35 oranında bağışık iken, sadece şap aşılaması yapılan grup 26/35 oranında bağıșıktır. 2. ayda simultane grup 35/35, şap grubu 34/34 oranında bağışık, 3 . ayda simultane grup $33 / 35$, şap grubu $33 / 34$ oranında bağışık, 6. ayda simultane grup 29/32, şap grubu
30/32 oranında bağıșıktır. Gruplardaki hayvanlarda korumayı sağlayan en düşük titre baz alınarak yapılan karşılaştırmalarda genel olarak birbirine yakın koruma düzeylerinin sağlandığ 1 görülmektedir. İstatistiki olarak yapılan karşılaştırmalarda eş zamanlı aşılama yapılan gruptaki hayvanlar ile yalnız şap aşılaması yapılan grup arasında A tipi antikor titresi açısından istatistiki olarak fark bulunmamış$\operatorname{tir}(\mathrm{p}>0,05)$.

Tablo 6. Konjuktival brusella ve şap aşısı uygulanan buzağılarda O tipi şap antikorlarının titre dağılımı

\begin{tabular}{|c|c|c|c|c|c|c|c|c|c|c|c|c|c|c|c|c|c|c|}
\hline & & & $<1 / 8$ & $1 / 8$ & $1 / 11$ & $1 / 16$ & $1 / 22$ & $1 / 32$ & $1 / 44$ & $1 / 64$ & $1 / 96$ & $1 / 128$ & $1 / 192$ & $1 / 256$ & $1 / 362$ & $1 / 512$ & $>1 / 512$ & n \\
\hline \multirow{6}{*}{ 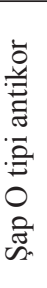 } & \multirow{2}{*}{ 14. Gün } & Ş+B & & & & & 1 & 1 & 2 & 3 & 1 & 3 & 4 & 5 & 3 & & 8 & 31 \\
\hline & & Ş & & & & & 1 & & 1 & 1 & 2 & 2 & 3 & 3 & 4 & & 12 & 29 \\
\hline & \multirow{2}{*}{ 28. Gün } & Ş+B & 4 & 3 & 5 & 6 & 2 & 3 & 1 & 3 & 2 & 1 & & & & & & 30 \\
\hline & & Ş & 7 & 3 & 3 & 4 & 3 & 2 & 5 & 1 & 1 & & & & & & & 29 \\
\hline & \multirow{2}{*}{ 2. Ay } & Ş+B & & & & & & 1 & 2 & 3 & 2 & 9 & 5 & 5 & 1 & & 2 & 30 \\
\hline & & Ş & & & & 1 & 1 & 1 & 3 & 2 & 3 & 2 & 4 & 5 & & & 6 & 28 \\
\hline
\end{tabular}


Açıklama: 14. gün sonuçlarına göre simultane aşılamada buzağıların 31/31'i bağışı iken sadece şap aşılamasında buzağıların 29/29'u bağışıktır. 28. günde simultane grup 12/30 oranında bağ 1 şı iken, sadece şap aşılaması yapılan grup 12/29 oranında bağışıktır. 28. günde şap aşısının rapeli yapılması ile 2. ayda simultane grup 30/30, şap grubu $27 / 28$ oranında bağışık olmuştur. Gruplardaki hayvanlar- da korumayı sağlayan en düşük titre baz alınarak yapılan karşılaştırmalarda genel olarak birbirine yakın koruma düzeylerinin sağlandığı görülmektedir. İstatistiki olarak yapılan karşılaştırmalarda eş zamanlı aşılama yapılan gruptaki hayvanlar ile yalnız şap aşılaması yapılan grup arasında $\mathrm{O}$ tipi antikor titresi açısından fark bulunmamıştır $(\mathrm{p}>0,05)$.

Tablo 7. Konjuktival brusella ve şap aşısı uygulanan buzağılarda A tipi şap antikorlarının titre dağılımı

\begin{tabular}{|c|c|c|c|c|c|c|c|c|c|c|c|c|c|c|c|c|c|c|}
\hline & & & $<1 / 8$ & $1 / 8$ & $1 / 11$ & $1 / 16$ & $1 / 22$ & $1 / 32$ & $1 / 44$ & $1 / 64$ & $1 / 96$ & $1 / 128$ & $1 / 192$ & $1 / 256$ & $1 / 362$ & $1 / 512$ & $>1 / 512$ & n \\
\hline \multirow{6}{*}{ 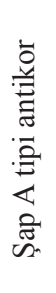 } & \multirow{2}{*}{ 14. Gün } & Ş+B & & 3 & 3 & 4 & 2 & 5 & 3 & 1 & 2 & 3 & 1 & 1 & 1 & 1 & 1 & 31 \\
\hline & & Ş & 4 & & 4 & 3 & 2 & 6 & 2 & 1 & 2 & 1 & 3 & & 1 & & & 29 \\
\hline & \multirow{2}{*}{ 28. Gün } & Ş+B & & 1 & 1 & 5 & 5 & 6 & 1 & 4 & & 3 & 1 & 1 & & & 1 & 29 \\
\hline & & Ş & 2 & 1 & 1 & 3 & 5 & 5 & 5 & 1 & 3 & 3 & & & & & & 29 \\
\hline & \multirow{2}{*}{ 2. Ay } & Ş+B & & & 1 & & 1 & & & & & & 3 & 2 & 10 & & 14 & 31 \\
\hline & & Ş & & & & & & & & 1 & 2 & 1 & & 6 & 5 & & 14 & 29 \\
\hline
\end{tabular}

Açıklama: 14. gün sonuçlarına göre simultane aşılamada buzağıların 21/31 oranında bağışık iken sadece şap aşılamasında buzağıların 18/29 oranında bağışıtır. 28. günde simultane grup 22/29 oranında bağışık iken, sadece şap aşılaması yapılan grup $22 / 29$ oranında bağış1ktır. 2 . ayda simultane grup 30/31 oranında şap grubu 29/29 oranında bağışıktır. Gruplardaki hayvanlarda korumayı sağlayan en düşük titre baz alınarak yapılan karşılaştırmalarda genel olarak birbirine yakın koruma düzeylerinin sağlandığı görülmektedir. Eş zamanlı grubun antikor titresi ile yalnız şap aşılaması yapılan grubun antikor titresi arasında istatistiki olarak fark tespit edilmemiştir $(\mathrm{p}>0,05)$.

\section{Serum aglütinasyon testi sonuçları}

Aglütinasyon testi ile brusella antikor titresi belirlenmiştir. $\mathrm{Bu}$ testte 1/10 antikor titresi humoral immun yanıtın kabul edildiği en küçük titre değeri olarak kabul edilmiştir. Parenteral çalışmada brusella maternal antikoru bulunmazken, konjuktival çalışmada 3 hayvanda $1 / 10$ titrede maternal antikor tespit edilmiştir. Bu hayvanlar gruplara homojen şekilde dağılmıştır.
Tablo 8. Parenteral brusella ve şap aş1s1 uygulanan buzağılarda brusella antikor titre dağılımı

\begin{tabular}{|c|c|c|c|c|c|c|c|c|c|c|}
\hline & & & $<1 / 10$ & $1 / 10$ & $1 / 20$ & $1 / 40$ & $1 / 80$ & $1 / 160$ & $\geq 1 / 320$ & n sayısı \\
\hline \multirow{12}{*}{ 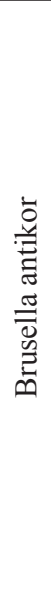 } & \multirow{2}{*}{ 14. Gün } & Ş+B & & & & 1 & 4 & 2 & 1 & 8 \\
\hline & & B & & & & 1 & 1 & 2 & 3 & 7 \\
\hline & \multirow{2}{*}{ 28. Gün } & Ş+B & & & 2 & 2 & 3 & 1 & & 8 \\
\hline & & B & & & 1 & 2 & 4 & & & 7 \\
\hline & \multirow{2}{*}{ 2. Ay } & Ş+B & 1 & 4 & 2 & & & & & 7 \\
\hline & & B & & 1 & 6 & & & & & 7 \\
\hline & \multirow{2}{*}{ 3. Ay } & Ş+B & 1 & 5 & 1 & & & & & 7 \\
\hline & & Ş & 1 & 6 & & & & & & 7 \\
\hline & \multirow{2}{*}{ 6. Ay } & Ş+B & 7 & & & & & & & 7 \\
\hline & & B & 6 & & & & & & & 6 \\
\hline & \multirow{2}{*}{ 12. Ay } & Ş+B & 5 & & & & & & & 5 \\
\hline & & B & 5 & & & & & & & 5 \\
\hline
\end{tabular}


Açıklama: 14. gün ve 28. gün sonuçlarına göre hem simultane hem brusella aşısı yapılan gruptaki hayvanların tamamında immun yanıt şekillenmiştir. 2 . ayda simultane grup $6 / 7$, brusella grubu $7 / 7$ oranında immun yanıt vermiştir. 3. ayda simultane grup ve brusella grubu 6/7 oranında immun yanıt vermiştir. 6 ve 12. Aylarda hayvanlarda immun yanit belirlenememiștir. Bunun sebebi çalışmada kullanılan buzağıların 90-117 günlük olması ve brusella aş1- sında genç hayvanlardaki humoral immun yanıtın kısa sürmesinden kaynaklandığı düşünülmektedir. Gruplardaki hayvanlarda korumayı sağlayan en düşük titre baz alınarak yapılan karşılaştırmalarda genel olarak birbirine yakın koruma düzeylerinin sağlandığ1 görülmektedir. Sadece 2. ayda brusella grubu istatistiki olarak simultane gruptan daha yüksek titre değeri vermiştir $(\mathrm{p}<0,05)$.
Tablo 9. Parenteral brusella ve şap aş1s1 uygulanan kuzularda brusella antikor titre dağılımı

\begin{tabular}{|c|c|c|c|c|c|c|c|c|c|c|}
\hline & & & $<1 / 10$ & $1 / 10$ & $1 / 20$ & $1 / 40$ & $1 / 80$ & $1 / 160$ & $\geq 1 / 320$ & n say1s1 \\
\hline \multirow{12}{*}{ 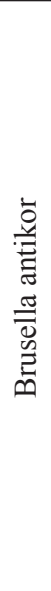 } & \multirow{2}{*}{ 14. Gün } & Ş+B & 1 & 2 & & 1 & 9 & 15 & 7 & 35 \\
\hline & & B & 1 & 1 & & 1 & 12 & 15 & 4 & 34 \\
\hline & \multirow{2}{*}{ 28. Gün } & Ş+B & & & 5 & 17 & 10 & 3 & & 35 \\
\hline & & B & 2 & 2 & 3 & 16 & 9 & 2 & & 34 \\
\hline & \multirow{2}{*}{ 2. Ay } & Ş+B & 9 & 11 & 11 & 3 & & & & 34 \\
\hline & & B & 11 & 10 & 9 & 3 & & & & 33 \\
\hline & \multirow{2}{*}{ 3. Ay } & Ş+B & 11 & 13 & 10 & & & & & 34 \\
\hline & & B & 18 & 11 & 2 & 1 & & & & 32 \\
\hline & \multirow{2}{*}{ 6. Ay } & Ş+B & 14 & 16 & 1 & & & & & 31 \\
\hline & & B & 21 & 9 & 1 & & & & & 31 \\
\hline & \multirow{2}{*}{ 12. Ay } & Ş+B & 18 & 9 & & & & & & 27 \\
\hline & & B & 17 & 6 & & & & & & 23 \\
\hline
\end{tabular}

Açıklama: 14. gün simultane grup $34 / 35$ oranında, brusella grubu 33/34 oranında ve 28 . gün sonuçlarına göre simultane grup 35/35 oranında brusella grubu 32/34 oranında, 2. ay simultane grup $25 / 34$ oranında brusella grubu 22/33 oranında, brusella grubu 22/33 oranında, 3. Ay simultane grup 23/34 oraninda, brusella grubu 14/32 oranında, 6 . Ay simultane grup 17/31 oranında brusella grubu 10/31 oranında, 12 ay simultane grup $9 / 27$, brusella grubu 6/23 oranında immun yanıt göstermiştir. İmmun yanıtın bu kadar uzun sürmesinin sebebi kuzuların 3-6 aylık olmasından kaynaklandığı düşünülmektedir. Gruplardaki kuzularda immun yanıt baz alınarak yapılan karşılaştırmalarda genel olarak simultane grupta daha yüksek immun yanıt alındığ görülmektedir. Tüm karşılaştırmalarda eş zamanlı gruptan istatistiki olarak daha yüksek antikor titresi elde edilmiştir (tüm gruplarda $\mathrm{p}<0,005$ ).

Tablo 10. Konjuktival brusella ve şap aşısı uygulanan buzağılarda brusella antikor titre dağılımı

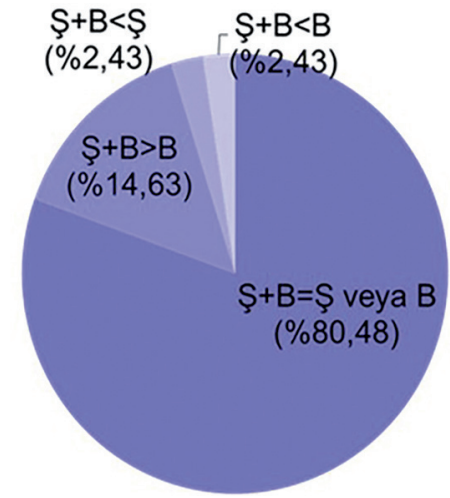

Şekil 1. Grup karşılaştırmalarının yüzdesel değerleri.

Çalışmanın yapıldığ grupların 41 adet karş1laştırmasında istatistiksel olarak \%80,48'inde (33 adet) simultane aşılama ile tek aşılama yapılan grup arasında farklılık tespit edilmemiştir ( $\mathrm{p}>0.05)$. Grupların \%14,63'ünde (6 adet) Parenteral Brusella ve Şap aşısı uygulanan kuzularda 14. gün, 28. gün, 2. ay, 3 . ay, 6 . ay ve 12 . ayın kan numunelerinde simultane grubun brusella antikor titresi sadece brusella aşısı yapılan grubun antikor titresine göre istatistiki 
olarak yüksektir ( $\mathrm{p}<0.05)$. Grupların \%2,43'ünde(1 adet) Parenteral Brusella ve Şap aşısı uygulanan kuzularda 2. ayda $\mathrm{O}$ tipi şap antikor titresi simultane aşılanan grubun antikor titresinden istatistiki olarak yüksektir $(\mathrm{p}<0.05)$. Bunun sebebi olarak simultane grupta maternal antikor gösteren hayvan $1 / 35$ oranında iken şap grubunda 32/35 olmasından kaynaklandığı düşünülmektedir. Çalışmadaki kuzuları yetiştiren işletme kayıtlarında kuzuların doğum tarihi bulunmadığından gruplandırmada yaş esas alınama- mıştır. Gruplardan \%2,43'ünde (1 adet) Parenteral Brusella ve Şap aşısı uygulanan buzağılarda 2. ayda Brusella grubunun antikor titresi simultane aşılanan grubun antikor titresinden istatistiki olarak yüksek$\operatorname{tir}(\mathrm{p}<0.05)$.

Karş1laştırmaların 33 adedinde $p>0.05$ bulunarak gruplar arası istatistiki fark bulunmamıştır. $\mathrm{p}<0,05$ sonucu ile istatistiki fark olan 8 gruptaki istatistiki analiz sonuçları şu şekildedir:

Tablo 11. İstatistiki sonuçlar

\begin{tabular}{|c|c|c|c|c|c|}
\hline Brusella ve şap aşı grupları & Grup & Arit. ort. & Standart sapma & p değeri & Sonuç \\
\hline \multirow{2}{*}{$\begin{array}{l}\text { Parenteral brusella ve şap buzağ } 1 \\
\text { 2. Ay brusella antikor titresi karşıllaştırma }\end{array}$} & Ş+B & 1,0429 & 0,20702 & 0,033 & \multirow{2}{*}{$(\mathrm{B}>\mathrm{S}+\mathrm{B})$} \\
\hline & B & 1,2571 & 0,11339 & 0,039 & \\
\hline \multirow{2}{*}{$\begin{array}{l}\text { Parenteral brusella ve şap kuzu } \\
\text { 2. Ay O tipi şap antikor titresi karş1laştırma }\end{array}$} & Ş+B & 1,3403 & 0,39855 & 0,002 & \multirow{2}{*}{$(\mathrm{S}>\mathrm{S}+\mathrm{B})$} \\
\hline & Ş & 1,6321 & 0,36231 & 0,002 & \\
\hline \multirow{2}{*}{$\begin{array}{l}\text { Şap ve parenteral brusella kuzu } \\
\text { 14. Gün brusella antikor titresi karşılaştırma }\end{array}$} & Ş+B & 2,1074 & 0,49476 & 0,000 & \multirow{2}{*}{$(\mathrm{S}+\mathrm{B}>\mathrm{B})$} \\
\hline & B & 2,0688 & 0,42758 & 0,000 & \\
\hline \multirow{2}{*}{$\begin{array}{l}\text { Şap ve parenteral brusella kuzu } \\
\text { 28. Gün brusella antikor titresi karş1laştırma }\end{array}$} & Ş+B & 1,6943 & 0,24964 & 0,003 & \multirow{2}{*}{$(\mathrm{S}+\mathrm{B}>\mathrm{B})$} \\
\hline & B & 1,6000 & 0,35420 & 0,003 & \\
\hline \multirow{2}{*}{$\begin{array}{l}\text { Şap ve parenteral brusella kuzu } \\
\text { 2. Ay brusella antikor titresi karş1laştırma }\end{array}$} & Ş+B & 1,0176 & 0,26568 & 0,007 & \multirow{2}{*}{$(\mathrm{S}+\mathrm{B}>\mathrm{B})$} \\
\hline & B & 1,0455 & 0,31927 & 0,007 & \\
\hline \multirow{2}{*}{$\begin{array}{l}\text { Şap ve parenteral brusella kuzu } \\
\text { 3. Ay brusella antikor titresi karşılaştırma }\end{array}$} & Ş+B & 0,9912 & 0,23915 & 0,000 & \multirow{2}{*}{$(\mathrm{S}+\mathrm{B}>\mathrm{B})$} \\
\hline & B & 0,8688 & 0,22781 & 0,000 & \\
\hline \multirow{2}{*}{$\begin{array}{l}\text { Şap ve parenteral brusella kuzu } \\
\text { 6. Ay brusella antikor titresi karşılaştırma }\end{array}$} & Ş+B & 0,8742 & 0,16925 & 0,000 & \multirow{2}{*}{$(\mathrm{S}+\mathrm{B}>\mathrm{B})$} \\
\hline & B & 0,8065 & 0,16520 & 0,000 & \\
\hline \multirow{2}{*}{$\begin{array}{l}\text { Şap ve parenteral brusella kuzu } \\
\text { 12. Ay brusella antikor titresi karşılaştırma }\end{array}$} & Ş+B & 0,8000 & 0,14412 & 0,000 & \multirow{2}{*}{$(\mathrm{S}+\mathrm{B}>\mathrm{B})$} \\
\hline & B & 0,7783 & 0,13469 & 0,001 & \\
\hline
\end{tabular}

\section{Tartışma ve Sonuç}

Serum nötralizasyon test sonuçlarına göre buzağ1larda uygulanan şap ve parenteral brusella aşılamalarında 6. ay sonuçları O tipi antikor titreleri A tipine sonuçlarına göre nispeten daha düşük çıkmıştır. $\mathrm{Bu}$ durum $\mathrm{O}$ tipi virüs yapısından kaynaklanan genel olarak O tipinde bağışıklığın kısa sürmesinden kaynaklanmaktadır. Şap ve parenteral brusella aş1ları uygulanan kuzulardaki O ve A tipi antikor titrelerinin buzağılardaki antikor titrelerinden nispeten yüksek olduğu görülmektedir. Bu durum kuzuların 3-6 aylık yaşta olması, buzağıların 90-117 günlük olması ile kuzuların yaşları sebebi ile immun sistemlerinin daha gelişmiş olması ile izah edilebilmektedir. Keza aynı sebepten konjuktival brusella çalışmasında kullanılan buzağıların 95-178 günlük olması parenteral çalışmada kullanılan 90-117 günlük buzağılardan daha yüksek şap antikor titresi elde edilmesine yol açmıştır. Parenteral brusella ve şap aşısı uygulanan kuzuların 2. ayda $\mathrm{O}$ tipi şap antikor titresi sadece şap aşılaması yapılan grubun antikor titresinden istatistiki olarak düşüktür. Bunun, simultane grupta maternal antikor gösteren hayvan 1/35 oranında iken şap grubunda 32/35 olmasından kaynaklandığı düşünülmektedir. Çalışmadaki kuzuları yetiştiren işletme kayıtlarında kuzuların doğum tarihi bulunmadığından gruplandırmada yaş esas alınamamıştır. İlk aşının yapıldığı gün aynı zamanda 0. gün kanları alındığından şap grubuna maternal antikoru olan kuzular tesadüfi olarak bir araya gelmiştir. 
Serum aglütinasyon test sonuçlarına göre buzağılardaki parenteral aşılamada brusella antikorları 3. aydan sonra titre vermezken konjuktival aşılamada 28. günden sonra titre vermemiştir. Bu konjuktival aşı içerisindeki CFU (colony forming unit) ile ilgili beklenen bir durumdur. Kuzulardaki parenteral brusella antikorlarının 12. ayda dahi tespit edilmesi çalışmaya alınan kuzuların 3-6 aylık olması ve yaşları sebebi ile daha güçlü immun yanıt oluşturabilmesinden kaynaklandığı düşünülmektedir.

Parenteral brusella ve şap aşısı uygulanan kuzularda 14. gün, 28. gün, 2. ay, 3. ay, 6. ay ve 12 . ayın kan numunelerinde simultane grubun brusella antikor titresi sadece brusella aşısı yapılan grubun antikor titresine göre istatistiki olarak yüksektir. $\mathrm{Bu}$ durumun şap aşısının yă adjuvantı sayesinde olduğu düşünülmektedir. Adjuvantlar aşılarda depo etkisi oluşturarak immun sistemi daha fazla uyarmak için kullanılmaktadırlar. Adjuvantlar makrofajları stimule ederek elde edilen immunglobulin miktarını arttırmaktadırlar. Boersma ve arkadaşlarının [5] yaptığı çalışmaya göre yağlı adjuvantların uygulanmasında IL-1 en ön plana çıkan sitokindir. İnterlökinler hem humoral hem hücresel immun yanitın artmasında etkili olmaktadır. Allison ve ark. [1] yaptığ çalışmaya göre yağlı adjuvantlar interlökinler üzerindeki etkisi ile humoral yanıtta IgG1 cevabını arttırmaktadır. Brusella antikor titre tespiti için yapılan aglütinasyon testinde simultane aşılamada brusella antikor titresinin tek yapılan aşılamaya göre daha yüksek bulunmasının sebebi yă̆ adjuvanın interlökinler üzerindeki etkisi ile Ig oluşumunu arttırması olarak düşünülmektedir. Ayrıca Mastan ve arkadaşlarının [16] kobaylarda yaptığı çalışmaya göre canlı brucella S-19 ve şap aşıları gerek simultane gerekse kombine olarak uygulandığında tek yapılan canlı brusella aşılamasına göre daha iyi eprüvasyon sonuçları vermiştir. Ayrıca canlı brusella S19 ile kombine şap aşılarının inaktif brusella S19 ile kombine şap aşılarına göre titre değerleri ve eprüvasyon değerleri daha yüksek çıkmıştır. Bu durum şap aşısı içerisindeki yağ adjuvantının inter-

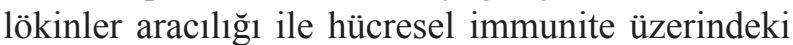
etkisini göstermekte ve çalışmamız ile aynı sonucu paylaşmaktadır. Başka bir çalışmada De Clercq ve ark. [8] domuz yavrularına inaktif, adjuvantlı şap ve attenüe klasik domuz ateşi aşılarını simultane uygulamışlardır. Simultane yapılan aşılamada klasik domuz ateşine karşı oluşan antikor miktarı tek aşı yapılan gruba göre daha yüksek elde edilmiştir. $\mathrm{Bu}$ çalışma da bulduğumuz sonucu desteklemektedir.

Sonuç olarak çalışmada brusella ve şap aşılarının simultane olarak uygulanmasında şap aşısı açısından bir titre kaybı olmadığı belirlenmiştir. Brusella ve şap aşılarının eş zamanlı uygulanmasinda brusellaya karșı oluşan humoral yanıt olumlu etkilenip daha yüksek antikor titresi vermiştir. Brusella aşısı attenüe bir aşı olduğundan hücresel immunite ile bağışıklık oluşturmaktadır. Humoral immunite de şekillenmektedir. Brucella aşısı ile elde edilen hücresel immunite günümüzde herhangi bir test ile tespit edilememektedir. Aynı zamanda yeterli olanaklar olmaması nedeni ile brusella aşıs1nın eprüvasyon çalışması yapılamamıştır.

\section{Teșekkür}

Değerli destekleri için Şap Enstitüsü İdaresi’ne, Şap Enstitüsü Epidemiyoloji Ünitesi ve Kalite Kontrol Bölümü çalışanlarına, TAGEM'e, TİGEM'e, Altınova Tarım İşletmesi Müdürlüğü’ne ve Pendik Veteriner Kontrol Enstitüsü Müdürlüğü’ne teşekkür ederiz.

\section{Kaynaklar}

1-Allison AC., Byars NE., 1991. Immunological adjuvants: desirable properties and side-effects. Mol Immunol, 28, 27984.

2-Altay G., 2008. Kültür pozitif 70 bruselloz hastasının klinik ve laboratuvar verilerinin değerlendirilmesi, Antibiyotik duyarlılıklarının e-test yöntemi ile incelenmesi. http:// www.istanbulsaglik.gov.tr/w/tez/pdf/enfeksiyon/dr_gulustan_altay.pdf Erişim Tarihi: 17.01.2010.

3-Anonim, 2010. Şap Hastalığı. http://www.kkgm.gov.tr/birim/ hay_sagl/Hastaliklar/sapy.html Erişim Tarihi: 17.01.2010.

4-Aslantaş Ö., 2006. Sı̆̆ır brusellozis'inin allerjik deri testleri ile teşhisi üzerinde çalışmalar. Kafkas Üniv Vet Fak Derg, 12, 57-61.

5-Boersma WJA., Bogaerts WJC, Bianchi ATJ., Claassen E., 1992. Adjuvant properties of stable water-in-oil emulsions: evaluation of the experience with Specol. Res Immunol, $143,503-512$.

6-Castaneda J., Espinoza M., Bernel C., Jimenez J., Aguirre L., 1976. Simultaneous vaccination of cattle with against foot and mouth disease and stomatitis live virus vaccines. Dev Biol Stand, 35, 429-36.

7-Davies G., 2002. Foot and mouth disease review. Res Vet Sci, 73, 195-199.

8-De Clercq K., Koenen F., Strobbe R., Debecq J., 1989. Simultaneous vaccination of piglets against foot-and- 
mouth disease and classical swine fewer. Vet Microbiol, 20, 215-221.

9-Favre H., Valette L., Precausta P., Roulet C., Brun A., Terre J., Fontaine J., Stellmann C., 1976. Les vaccines antiaphteux associes a dautres vaccines bacteries ou viraux. Dev Biol Stand, 35, 409-428.

10-Hedger RS., Taylor WP., Barnett TR., Riek R., Harpham D., 1986. Simultaneous vaccination of cattle against rinder pest and FMD. Trop Anim Hith Prod, 21-25.

11-Ivanyi TS., Kucsera G., Tubaly S., Bognar K., Kiss S., Bernath Z., 1981. Immunogenenicity of attenuated VD and inactivated FMD vaccines applied alone or simultaneously. Magyar Allotorvosok Lapja, 36, 369-373.

12-Kitching RP., 2002a. Clinical variation in foot and mouth disease: Cattle. Rev Sci Tech Off Int Epiz, 21, 499-504.

13-Kitching RP., 2002b. Future resarch on foot and mouth disease. Rev Sci Tech Off Int Epiz, 21, 885-889.

14-Küçükayan U., Dakman A., Ülker U., Müştak K., 2007. Koyun kan serumları ve fetusların bakteriyel atı etkenleri yönünden incelenmesi. Etlik Vet Mik Derg, 18, 11-16.
15-Mahy BWJ., 2005. Foot and mouth disease virus. Springer Limited, Berlin, s. 133-135.

16-Mastan MB., Amighi M., Ardelan A., Bandpay MR., Ebadi A., Farsi J., 1976. Preliminary study of the combination of anti-foot-and-mouth disease and anti-brucellosis vaccines. Dev Biol Stand, 35, 437-43.

17-Srinivas K., Babu N., Kant R., Rahasekhar M., Kumar M., 1996. Simultaneous vaccination against foot and mouth disease. Indian Jour of Vir, 12, 33-7.

18-Stevens MG., Hennager SG., Olsen SC., Cheville NF., 1993. Serologic respons in diagnostic tests for brucellosis in cattle vaccinated with Brucella abortus 19 or RB51. J Clinic Microbiol, 1065-1066.

19-Şap Enstitüsü Protokolü p:D/9.1.

20-Ünver A., Erdoğan HM., Atabay Hİ., Şahin M., Güneş V., Çıtıl M., Gökçe Hİ., 2006. Sığır atıklarından izole edilen Brucella türlerinin RAPD-PCR ile genotiplendirilmesi. Kafkas Üniv Vet Fak Derg, 12, 121-127. 